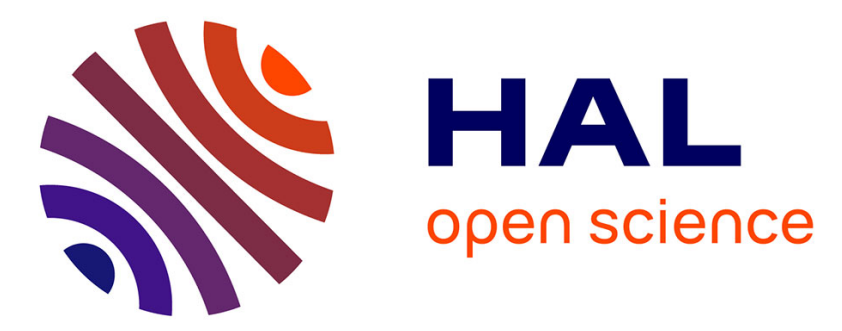

\title{
Realization of a High-Current and Low RON 600V Current-Limiting Device
}

F. Nallet, Phillippe Godignon, Dominique Planson, Christophe Raynaud, Jean-Pierre P Chante

\section{- To cite this version:}

F. Nallet, Phillippe Godignon, Dominique Planson, Christophe Raynaud, Jean-Pierre P Chante. Realization of a High-Current and Low RON 600V Current-Limiting Device. Materials Science Forum, 2002, 389-393, pp.1247-1250. 10.4028/www.scientific.net/MSF.389-393.1247 . hal-02151717

\section{HAL Id: hal-02151717 \\ https://hal.science/hal-02151717}

Submitted on 9 Jun 2019

HAL is a multi-disciplinary open access archive for the deposit and dissemination of scientific research documents, whether they are published or not. The documents may come from teaching and research institutions in France or abroad, or from public or private research centers.
L'archive ouverte pluridisciplinaire HAL, est destinée au dépôt et à la diffusion de documents scientifiques de niveau recherche, publiés ou non, émanant des établissements d'enseignement et de recherche français ou étrangers, des laboratoires publics ou privés. 


\title{
Realization of a High Current and Low $R_{\mathrm{ON}} 600 \mathrm{~V}$ Current Limiting Device
}

\author{
F. Nallet ${ }^{1}$, P. Godignon ${ }^{2}$, D. Planson ${ }^{1}$, C. Raynaud ${ }^{1}$, J.P. Chante ${ }^{1}$ \\ ${ }^{1}$ Centre de Génie Electrique de Lyon (CEGELY), UMR N 5005 - Insa de Lyon, bât. L. de Vinci, 20, \\ av. A. Einstein - F-69621 Villeurbanne Cedex, France \\ ${ }^{2}$ Centro Nacional de Microelectronica (CNM), Campus Universidade \\ Autonoma de Barcelona, 08193 Bellaterra, Barcelona, Spain.
}

Keywords : 4H-SiC, MOSFET, Current Limiting Device, Simulation, I-V Characteristics, Forward Current Density, Saturation.

\begin{abstract}
The first experimental results of a $600 \mathrm{~V} 4 \mathrm{H}-\mathrm{SiC}$ current limiting device are shown. This device limits the current as the bias voltage increases. The forward conduction is ensured by an $\mathrm{N}$ type implanted channel (doping species: nitrogen) on top of a $\mathrm{P}^{+}$implanted layer (doping species: aluminum). The prototypes reach a saturation current density of $900 \mathrm{Acm}^{-2}$, with a specific on-resistance of $13 \mathbf{m} \Omega \mathrm{cm}^{2}$. The $4 \mathrm{H}-\mathrm{SiC}$ current limiting devices belong to the best set of Accu-MOSFETs devices reported in the literature.
\end{abstract}

\section{Introduction}

Silicon carbide technologies for the manufacturing of power devices seem to be promising in the near future. The first SiC power devices commercially available are Schottky diodes proposed by Infineon technologies (ranging: $300 \mathrm{~V} / 10 \mathrm{~A}$ and $600 \mathrm{~V} / 4-6 \mathrm{~A}$ ) and Microsemi. In the field of the SiC switches, the current trends are the Accu-MOSFET and JFET structures which exhibit the best specific on-

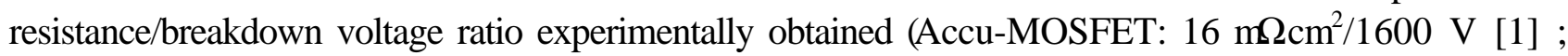
JFET: $10 \mathrm{~m} \Omega \mathrm{cm}^{2} / 600 \mathrm{~V}$ [2], $14 \mathrm{~m} \Omega \mathrm{cm}^{2} / 1800 \mathrm{~V}$ [2]). The physical properties of $\mathrm{SiC}$ allow to develop new solid state devices for applications not covered by the silicon technologies. In this sense, a silicon carbide current limiting component should be a solid state structure which has to work under high voltage and high temperature conditions when a short-circuit current appears. The function requires to limit a shortcircuit overcurrent during a time long enough to allow the opening of the power line by a circuit breaker under reliable conditions. Such a $4 \mathrm{H}-\mathrm{SiC}$ component corresponding to the End User specified requirements $(600 \mathrm{~V} / 50 \mathrm{~A})$ led to the definition of the device technological parameters assisted by the finite-element simulation software DESSIS ISE ${ }^{\circledR}$ developed by ISE $^{\mathrm{TM}}$ TCAD [3]. The electrical static behavior of the first process run, realised at CNM (Barcelona), are discussed and led us to change some technological parameters in order to reduce the specific on-resistance and increase the saturation current density.

\section{Device structure, simulation and technology}

The design of the component is based on an Accu-MOSFET device whose structure is presented in Fig. 1. The wafer is composed by a $\mathrm{N}^{++}$substrate layer $(\rho=20 \mathrm{~m} \Omega . \mathrm{cm} / 430 \mu \mathrm{m})$ on which a $\mathrm{N}$ type epitaxial layer $\left(4 \times 10^{15} \mathrm{~cm}^{-3} / 7 \mu \mathrm{m}\right)$ was grown (purchased from CREE Research). A single Al implantation is used for the realization of the buried $\mathrm{P}^{+}$region and the guard ring protection. Then, a full wafer multiple $\mathrm{N}$ implantation is processed to implement the $\mathrm{N}$-channel (the $\mathrm{N}$ implantation come over the $\mathrm{Al}$ implantation, so the $\mathrm{N}$-channel is a high compensated N-layer). After that, $\mathrm{N}^{++}$implantation for ohmic source contact, $\mathrm{SiC}$ etching to reach the $\mathrm{P}^{+}$layer, dry oxidation and both side metallization are processed to manufacture the device without passivation layer. In case of positive drain to source voltage bias, the conduction current is carried by the electrons whose path inside the device crosses the entire thickness of the wafer, the 'intercell' region and the channel region successively. Fig. 1 shows the device structure with its guard ring protection. 


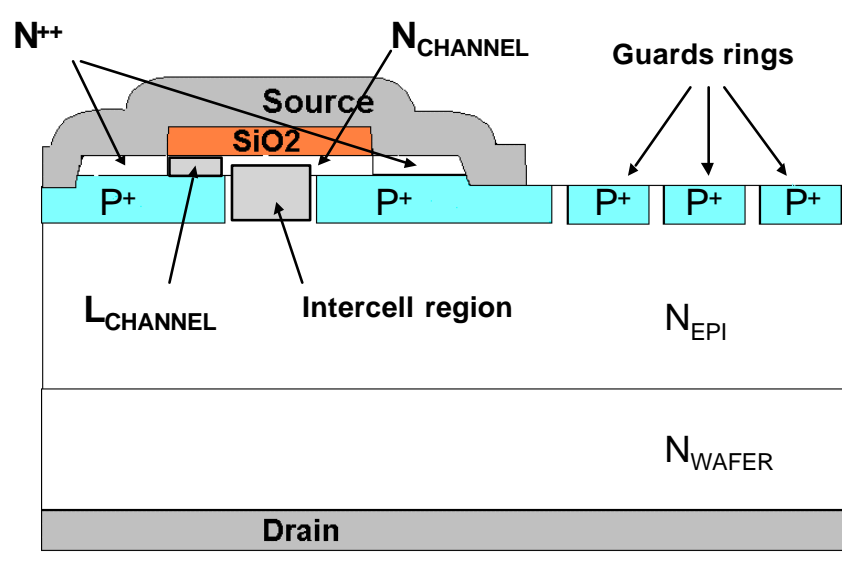

Fig. 1: Vertical cross section of the device and its guard ring peripheral protection (the channel region,

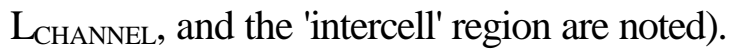

For a drain to source voltage $\mathrm{V}_{\mathrm{DS}}>0 \mathrm{~V}$, the drain to source current $\mathrm{I}_{\mathrm{DS}}$ increases linearly with $\mathrm{V}_{\mathrm{DS}}$. When the device reached the saturation mode, the current can not increase any more because the reverse space

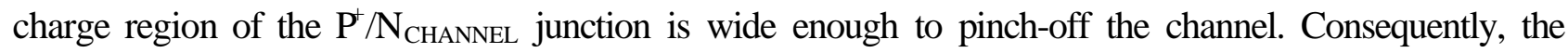
device is normally-on and the current limiting behavior is unidirectional (for $\mathrm{V}_{\mathrm{DS}}>0 \mathrm{~V}$ ). Electrical simulations, with DESSIS ISE ${ }^{\circledR}$ [3], were performed [4] to optimize the structure characteristics : low onresistance (10-20 $\left.\mathrm{m} \Omega \mathrm{cm}^{2}\right)$ and high saturation current density (500-1000 $\mathrm{Acm}^{-2}$ ). The technological choices led to a 6 mask levels process using standard process steps commonly used in a Si clean room except for the high temperature post-implantation annealing which is realized in our specific annealing equipment. The device voltage handling capability is $700 \mathrm{~V}$ with the specified epitaxial layer and a non optimized guard ring protection. The expected I-V characteristics given by a DESSIS ISE ${ }^{\circledR}$ simulation using implanted doping profiles simulated by a specific software developed by E. Morvan [5] are shown in Fig. $2\left(\mathrm{P}^{+}: 350 \mathrm{keV} / 4 \times 10^{13} \mathrm{~cm}^{-2}\right.$; $\left.\mathrm{N}_{\text {CHANNEL }}: 30-180 \mathrm{keV} / 1.3 \times 10^{13} \mathrm{~cm}^{-2}\right)$.

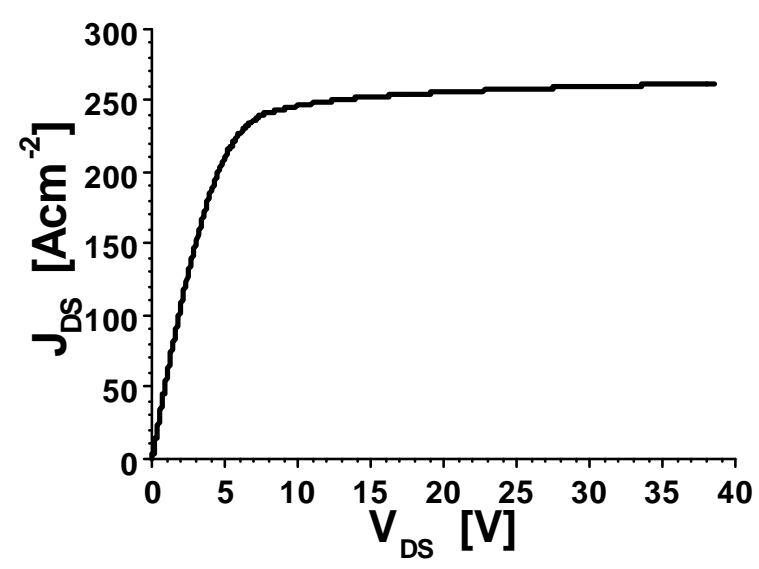

Fig. 2: Device static I-V simulation results obtained by DESSIS ISE ${ }^{\circledR}$ on a limiting device with the following parameters: $\left(\mathrm{P}^{+}: 350 \mathrm{keV} / 4 \times 10^{13} \mathrm{~cm}^{-2} ; \mathrm{N}_{\mathrm{CHANNEL}}: 30-180 \mathrm{keV} / 1.3 \times 10^{13} \mathrm{~cm}^{-2}\right)$.

\section{Experimental results}

The prototypes are designed following a multiple hexagonal cells device, with different values of the channel length $(4,5$ and $6 \mu \mathrm{m})$ and the 'intercell' width $(4,6$ and $8 \mu \mathrm{m})$ (see Fig. 1). The active area (surface of the source contact) is about $0.05 \mathrm{~mm}^{2}$ and the conduction perimeter is $2880 \mu \mathrm{m}$.

In the first batch prototypes, ohmic contacts are made with nickel and annealed at $850^{\circ} \mathrm{C}$. The 'gate' oxide thickness is about $90 \mathrm{~nm}$ and the post-implantation annealing process used is $1700^{\circ} \mathrm{C}$ during $30 \mathrm{~min}$ in an inductive furnace. The electrical characteristics were measured using a Keithley K237 ( $\mathrm{P}_{\mathrm{MAX}}=10 \mathrm{~W}$ that means a $100 \mathrm{~mA} / 100 \mathrm{~V}$ range). The best devices show a normally-on behavior with a high specific on- 
resistance $\left(\mathrm{R}_{\mathrm{ON}-\mathrm{SPE}}\right)$ of $150 \mathrm{~m} \Omega \mathrm{cm}^{2}$ and a saturation current density of $150 \mathrm{Acm}^{-2}$. We observe a very soft saturation region as shown in the I-V characteristics of Fig. 3. The specific on-resistances obtained are very high compared to the expected value $\left(10-20 \mathrm{~m} \Omega \mathrm{cm}^{2}\right)$ (Fig. 2) and the saturation current region is not clearly demonstrated.

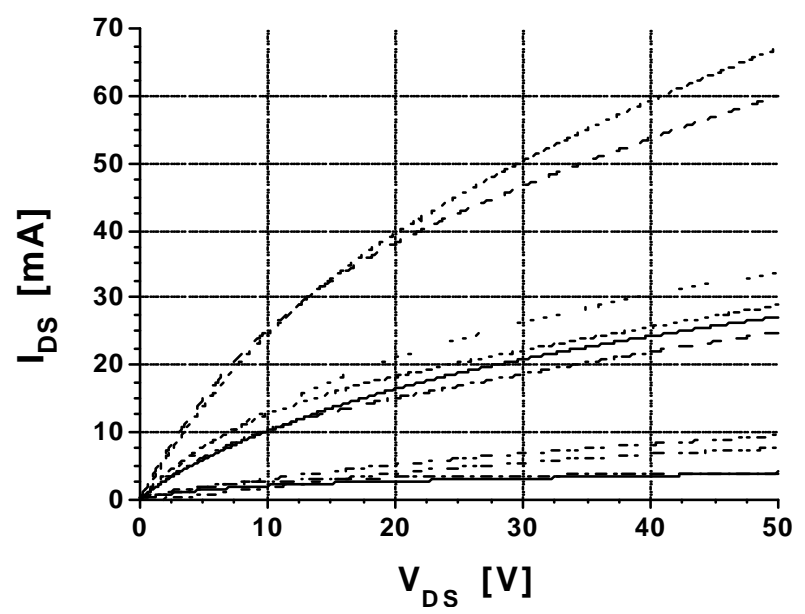

Fig. 3: Sampling of different I-V static characteristics obtained on limiting devices from the first batch $\left(25^{\circ} \mathrm{C}\right)$.

SIMS (Secondary Ion Mass Spectroscopy) analysis indicate a channel depth of $0.1 \mu \mathrm{m}$ with an average doping level of 2D $10^{17} \mathrm{~cm}^{-3}$. TLM (Transmission Line Method) measurements combined with the doping profiles (extracted from the SIMS profiles) allow us to estimate a channel electron mobility of $100 \mathrm{~cm}^{2} \mathrm{~V}^{-1} \mathrm{~s}^{-}$ ${ }^{1}$. The effective charge density at the $\mathrm{SiO}_{2} / 4 \mathrm{H}-\mathrm{SiC}$ interface were extracted from $\mathrm{C}-\mathrm{V}$ measurements and are found to be negative in the $1.5-2 \mathrm{D} 10^{12} \mathrm{~cm}^{-2}$ range. This explains the normally-off behavior of most devices $\left(\mathrm{SiO}_{2} / 4 \mathrm{H}-\mathrm{SiC}\right.$ interface charge density is close to the channel dose, $\left.2 \mathrm{D} 10^{12} \mathrm{~cm}^{-2}\right)$. To improve the device characteristics, some technological changes were used for the second prototypes realization. The static I-V characteristics (measured with a Tektronix 370 curve tracer) of the second run prototypes show a very good behavior. The effects of the channel length and the intercell width are clearly visible and indicate that the intercell width has a low effect on $\mathrm{R}_{\mathrm{ON}-\mathrm{SPE}}$, but decreasing $\mathrm{L}_{\mathrm{CHANNEL}}$ lead to clearly decrease $\mathrm{R}_{\mathrm{ON}-\mathrm{SPE}}$. The best specific on-resistances measured are in the $13-17 \mathrm{~m} \Omega \mathrm{cm}^{2}$ range (Fig. 4) and the highest saturation current density is $900 \mathrm{~A} \mathrm{~cm}^{-2}$ (Fig. 5), obtained for the devices designed with a channel length of $4 \mu \mathrm{m}$ and an intercell width of $8 \mu \mathrm{m}$. These results are not so far from the DESSIS ISE ${ }^{\circledR}$ simulations performed with the second run projected technological data. Further analysis will be necessary to extract the channel mobility and the $\mathrm{SiO}_{2} / 4 \mathrm{H}-\mathrm{SiC}$ interface charge density. Nevertheless, it seems that a high channel electron mobility (close to the simulation value, $400 \mathrm{~cm}^{2} \mathrm{~V}^{-1} \mathrm{~s}^{-1}$ ) is obtained with a low level of $\mathrm{SiO}_{2} / 4 \mathrm{H}-\mathrm{SiC}$ interface charge density, when comparing the simulated I-V characteristic (without $\mathrm{SiO}_{2} / 4 \mathrm{H}-$ $\mathrm{SiC}$ interface charge density specification) and the corresponding experimental results of Fig. 5. 


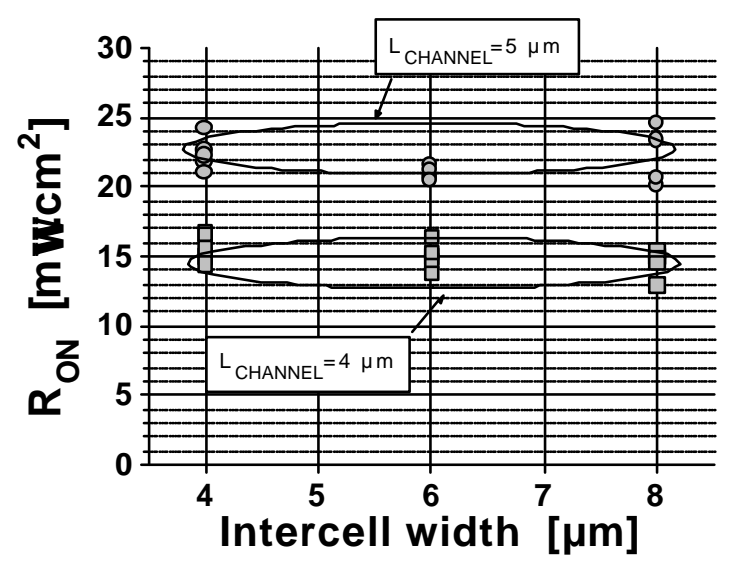

Fig. 4: Experimental Specific on-resistance plotted versus the intercell width.

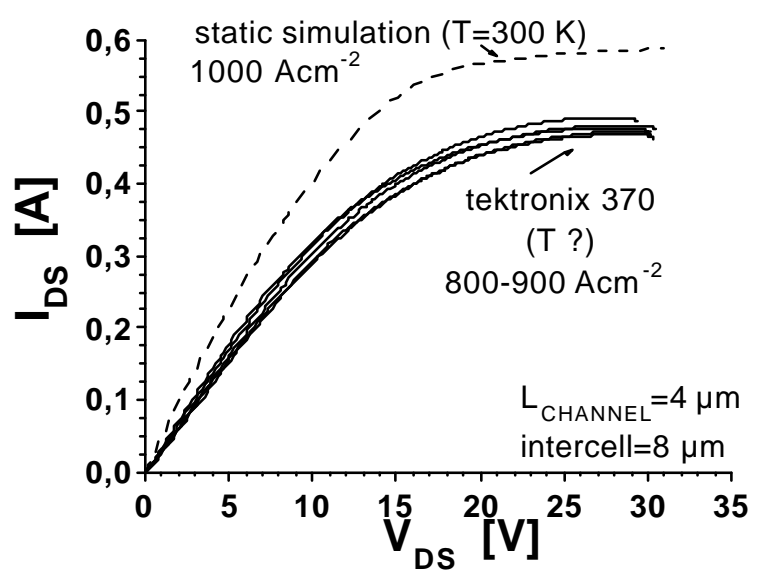

Fig. 5: Simulation/experiment comparison for current limiting devices (channel length: $4 \mu \mathrm{m} /$ intercell width: $8 \mu \mathrm{m})$. For the experimental results using the Tektronix 370 curve tracer, the temperature inside the device, particularly at the end of the channel, is unknown due to self heating (I-V characteristic was limited to $30 \mathrm{~V}$ to avoid the device destruction. The $600 \mathrm{~V}$ capability should require a pulsed method to avoid self heating and show the real I-V static characteristic).

\section{Conclusion}

In this paper we presented the first experimental results of a new normally-on Accu-MOSFET for current limitation applications. The fabricated devices show a very high saturation current density $\left(\mathbf{9 0 0} \mathbf{A c m}^{-2}\right)$ and a low specific on-resistance $\left(\mathbf{1 3} \mathbf{~} \mathbf{\Omega} \mathbf{~ c m}^{2}\right)$ without gate drive, close to the best characteristics reported for a JFET device [2] for the $600 \mathrm{~V}$ breakdown voltage range. The fabrication-technology used is based on an implanted channel and only 6 mask levels are necessary.

\section{Acknowledgment}

We acknowledge SCHNEIDER ELECTRIC S.A. for financial and technical supports, and CNM of Barcelona who manufactured the prototypes.

\section{References}

[1] J. Tan, J.A. Cooper, M.R. Melloch: IEEE Elec. Dev. Lett. Vol. 19 (1998), p.487

[2] P. Friedrichs, H. Mitlehner, K.O. Dohnke, D. Peters, R. Schöner, U. Weinert, E. Baudelot, D. Stephani: Int. Symp. Power Semicond. Dev. (2000), p. 213

[3] ISE Integrated System Engineering, DESSIS, Operator's manual

[4] F. Nallet, A. Senes, D. Planson, M.L. Locatelli, J.P. Chante, D. Renault: Int. Symp. Power Semicond. Dev. (2000), p. 287

[5] E. Morvan, PhD Thesis, INSA of Lyon (1999), 298 p. (in French) 